\title{
MOLECULAR RESPONSE IN PATIENTS WITH CHRONIC MYELOID LEUKEMIA TREATED WITH IMATINIB - SINGLE CENTRE EXPERIENCE
}

\author{
Marica Pavkovic, Rosica Angelkovic, Marija Popova-Simjanovska, \\ Sonja Genadieva-Stavric, Lidija Cevreska, Aleksandar Stojanovic
}

\author{
University Clinic for Hematology, Medical Faculty, Skopje, R. Macedonia
}

Corresponding Author: Marica Pavkovic, MD, PhD, University Clinic for Hematology, Faculty of Medicine, Skopje, ul. Vodnjanska 17, 1000 Skopje, Republic of Macedonia; Tel: ++389 70344 709, Fax: ++389 (0)2 32170 61;

E-mail:pavkovicm@yahoo.com

\begin{abstract}
Introduction of tyrosine kinase inhibitors (TKI) dramatically improves the treatment and survival of the patients with chronic myeloid leukemia (CML) in the last decade. Imatinib (IM) and other TKI induce larger percentage of complete cytogenetic response (CCyR) and major molecular response (MMR). Treatment resistance to TKIs still remains an important problem in the treatment of CML. The aim of our study was to analyze the molecular response (MR) in CML patients treated with Imatinib in our institution.

We have analyzed 53 CML patients (pts), 28 females and 25 males, treated with IM as a front or second line treatment. Only 15 pts were treated with IM as a front-line therapy, while 38 pts were pretreated with hydroxyurea or/and interferon. Median duration of CML was 6 years (range: 1 year17 years). Median duration of IM treatment was 3 years (range: 1 year-10 years). MR was analyzed in one up to 8 time points with Real Time Quantitative RT-PCR method.

Forty six pts (87\%) had complete hematological response and 55\% of pts had MMR, 13/53(24.5\%) pts had MMR at 4.0-4.5 log and 16/53(30.2\%) pts had MMR at 3.0-4.0 log. MMR was not achieved in $24 / 53(45.3 \%)$.

Our results have shown smaller percentage of patients (55\%) with MMR, mostly due to the fact that larger proportion of patients (38/53) were heavily pretreated with HU or/and Interferon for a prolonged period of time, before the IM treatment. This is a major risk factor for acquisition of additional molecular and cytogenetic abnormalities responsible for IM resistance and poor treatment response.
\end{abstract}

Key words: chronic myeloid leukemia, tyrosine kinase inhibitors, molecular response

\section{Introduction Introduction}

Chronic myeloid leukemia (CML) is an acquired clonal hematopoetic stem cell disorder characterized by the presence of Philadelphia $(\mathrm{Ph})$ chromosome $(\mathrm{t} 9 ; 22)$ and the expression of its molecular equivalent BCR-ABL1 oncoprotein [1-3]. CML was the first malignnancy associated with specific genetic defect $[1,2]$, reciprocal translocation of the long arms of chromosomes 9 and 22 ( $\mathrm{Ph}$ chromosome), resulting in a presence of a specific BCR-ABL1 transcript and aberrant expression of its product
ABL tyrosine kinase [3, 4]. These molecular discoveries lead to a development of highly effecttive, molecular targeted therapy with tyrosine kinase inhibitors like Imatinib [5, 6]. The introduction of tyrosine kinase inhibitors (TKI) dramatically improves the treatment and survival of the patients with chronic myeloid leukemia. Imatinib and other second generation TKI inhibitors (Nilotinib, Dasatinib) induce not only complete cytogenetic response but also a large percentage of optimal and deep molecular response $[7,8]$, but still treatment resistance to 
TKI remains an important problem in patients with CML.

Although the use of standard dose of Imatinib as a first line therapy dramatically improves the outcome of CML patients $[7,8]$, one third of the patients do not achieve optimal outcome, mostly due to drug resistance and require alternative therapies. Seven-year follow-up of CML patients treated with Imatinib as a front line therapy showed estimated 7-year overall survival of $86 \%$ and only $6 \%$ CML-related deaths [7]. Eight-year follow-up of the IRIS study showed $85 \%$ overall survival (OS) rate, but almost $30 \%$ of the patients had unfavorable outcome, mostly due to primary (17\%) or acquired imatinib resistance (15\%) [8].

According to the results of the IRIS study, in 2008 the European LeukemiaNet (ELN) group recommended frequent molecular monitoring (3, 6, 12, 18 months) of CML patients treated with TKIs and identifying the patients with suboptimal response or failure to imatinib as a first line treatment [8]. In 2013 these recommendations were updated and the term suboptimal response was excluded and resistant patients were identified based on the early molecular response [9].

The most common mechanisms of resistance to the TKIs treatment are the mutations in BCR-ABL1 kinase domain, additional chromosome aberrations and genetic abnormalities. Point mutations in BCR-ABL1 kinase domain are detectable in almost $50 \%$ of the patients with treatment failure and progression [10-12]. Additional cytogenetic abnormalities like monosomy 7, deletion of long arm of chromosome 7 (del 7q), as well as other complex karyotype abnormalities are associated with bad prognosis, shorten survival of CML patients and poor response to TKI therapy [13-15].

Nowadays, the response to TKI is the most important prognostic factor. In the era of second line TKIs (nilotinib, dasatinib, ponatinib) more sensitive methods for monitoring therapy response are necessary. Based on such more sensitive molecular monitoring, ELN introduced the terms "optimal" response and "failure". Optimal response is associated with the best long-term survival and indicates that there is no need for change in the treatment. Failure means that the patients should receive different treatment in order to limit disease progression and death. Pre- viously there was a term "suboptimal" response, an intermediate zone between optimal response and failure, (Table 1). These term is now changed with the term "warning" and this term implies that the disease require more frequent monitoring to prevent disease progression and treatment failure [9]. In the latest ELN recommendations early molecular response at the $3^{\text {rd }}$ month of initiating the TKI treatment and the deeper molecular response at any time are becoming more important prognostic factors that can influence further therapeuthical decisions [9].

The aim of our study was to analyze the molecular response (MR) in CML patients treated with Imatinib in our institution. The molecular response was defined as MMR after at least 12 months of therapy with IM. Earlier points of molecular monitoring (at 3, 6, 9 months) were not included in defining the MR in CML patients on IM.

\section{Materials and methods}

We have analyzed 53 CML patients (pts), treated with Imatinib as a front line or second line treatment. The hematological response was evaluated by routine hemogram and interprettation of peripheral blood smear stained with May Grunwald/ Giemsa method. The patients were in complete hematological response if they had normal hemogram (normal hemoglobin level, normal leukocyte and platelet numbers) and normal peripheral blood smears (without any leukocyte precursor cells like myelocytes, promyelocytes, blasts and normal number of basophiles and eosinophils).

The molecular response was analyzed in 1 up to 8 time points per patient; total of 267 analysis were performed with median number 4 (range: 1-8) with Real Time Quantitative RTPCR method. The RNA was isolated from peripheral blood mononuclear cells, by using $10 \mathrm{ml}$ venous blood with EDTA as anticoagulants. The RNA was isolated from the leucocytes preserved in TRI reagent following the manufacturer procedure and the RNA concentration was determined with spectrophotometer and adapted to $1 \mu \mathrm{g} / \mu \mathrm{L}$. Than the RNA was converted to cDNA by the method of reverse transcription by using ready-to-use kits by Qiagen, following the manufacturer procedure. Quantitative real time PCR was performed by using cDNA and ready-to use Qiagen BCR-ABL1 Quantitative 
Kits and Roche Light Cycler 1.2, following the manufacturer instruction. The results were calculated by using specially designed Excel Program and expressed as the level of BCR-ABL/ABL ratio. The patients were in major molecular response at $3 \log$ reduction, if the level of BCRABL1 transcript compared to ABL1 transcript level is $<0.1 \%$. The major molecular response at 3.0-4.0 log is defined as BCR-ABL1/ABL1 level between $0.1-0.01 \%$, while MMR at 4.0-
4.5 $\mathrm{log}$ is defined as BCR-ABL1/ABL1 level between 0.01-0.0032\%. MMR was not achieved when the BCR-ABL1 level was higher than 0.1 . We evaluate only the results from molecular monitoring after one year of IM treatment. The molecular results at 3, 6, 9 months were not considered in the evaluation of the molecular response, since the latest ELN recommendations define optimal molecular response as MMR achieved at 12 months (Table 1).

Table 1

Definition of the response to TKIs (any TKI) as first-line treatment recommended by ELN [9]

\begin{tabular}{|c|c|c|c|}
\hline & Optimal & Warning & Failure \\
\hline Baseline & NA & $\begin{array}{l}\text { High risk or } \mathrm{CCA} / \mathrm{Ph}+\text {, } \\
\text { major route }\end{array}$ & NA \\
\hline \multirow[t]{2}{*}{$3 \mathrm{mo}$} & $\mathrm{BCR}-\mathrm{ABL} 1 \leq 10 \%$ & \multirow{2}{*}{$\begin{array}{l}\text { BCR-ABL1 > } 10 \% \text { and/or } \\
\mathrm{Ph}+36-95 \%\end{array}$} & Non CHR and/or \\
\hline & and/or $\mathrm{Ph}+\leq 35 \%$ & & $\mathrm{Ph}+>95 \%$ \\
\hline \multirow{2}{*}{$6 \mathrm{mo}$} & $\mathrm{BCR}-\mathrm{ABL} 1 \leq 1 \%$ and/or & BCR-ABL1 1-10\% and/or & BCR-ABL1 $>10 \%$ \\
\hline & $\mathrm{Ph}+0$ & $\mathrm{Ph}+1-35 \%$ & and/or $\mathrm{Ph}+>35 \%$ \\
\hline \multirow{2}{*}{$12 \mathrm{mo}$} & BCR-ABL $1 \leq 0.1 \%$ and $/$ or & BCR-ABL1 > $0.1-1 \%$ & $\mathrm{BCR}-\mathrm{ABL} 1>1 \%$ \\
\hline & & and/or & and/or $\mathrm{Ph}+>0$ \\
\hline \multirow{5}{*}{$\begin{array}{l}\text { Then, and } \\
\text { at any time }\end{array}$} & \multirow[t]{5}{*}{$\mathrm{BCR}-\mathrm{ABL} 1 \leq 0.1 \%$} & \multirow[t]{5}{*}{ CCA/Ph-(-7 or 7q-) } & Loss of CHR \\
\hline & & & Loss of CCyR \\
\hline & & & Confirmed loss of \\
\hline & & & MMR, Mutations \\
\hline & & & $\mathrm{CCA} / \mathrm{Ph}+$ \\
\hline
\end{tabular}

$\mathrm{NA}$, not applicable; MMR, BCR-ABL1 $\leq 0.1 \%$ is MR at $3.0 \log$ or better; $\mathrm{CCA} / \mathrm{Ph}+$, clonal chromosome abnormalities in $\mathrm{Ph}+$ cells; $\mathrm{CCA} / \mathrm{Ph}$-, clonal chromosome abnormalities in $\mathrm{Ph}$ - cell.

\section{Results}

We have analyzed 53 CML patients, 28 females and 25 males, treated with Imatinib as a front line or second line treatment. Only 15 patients were treated with IM as a front-line therapy, while 38 patients were previously treated with hydroxyurea or/and interferon alpha. The median age of analyzed CML patients was 59 years (range: 18-77 years). Forty patients (75\%) were older than 45 years. The median duration of CML was 6 years (range: 1 year-17 years). The median duration of IM treatment was 3 years (range: 1 year-10 years).

The molecular response was analyzed in 1 up to 8 time points, depending on the disease duration. The results of the Real Time Qu- antitative RT-PCR from two patients, before and after the Imatinib treatment are shown in Figure 1. In both cases BCR-ABL1/ABL1 level was high $(45.5 \%$ and $67.4 \%)$ before the initiation of the Imatinib treatment. After 9 months of Imatinib treatment, BCR-ABL1/ABL1 level had dropped to 0.01 and $0.014 \%$ (Figure 1) and both patients achieved MMR.

Figure 2 presents hematological, cytogenetic and molecular response during the first 15 months of the Imatinib treatment in one of the patients. This patient achieved complete hematologic response after 3 months of IM treatment, the CCR was achieved after 12 months of treatment and the patient did not reach MMR after 15 months of treatment (last molecular monitoring 
point). The molecular results indicated that this patient did not achieve optimal response to IM, according to the latest ELN recommendations and should be considered for change of treatment [9].
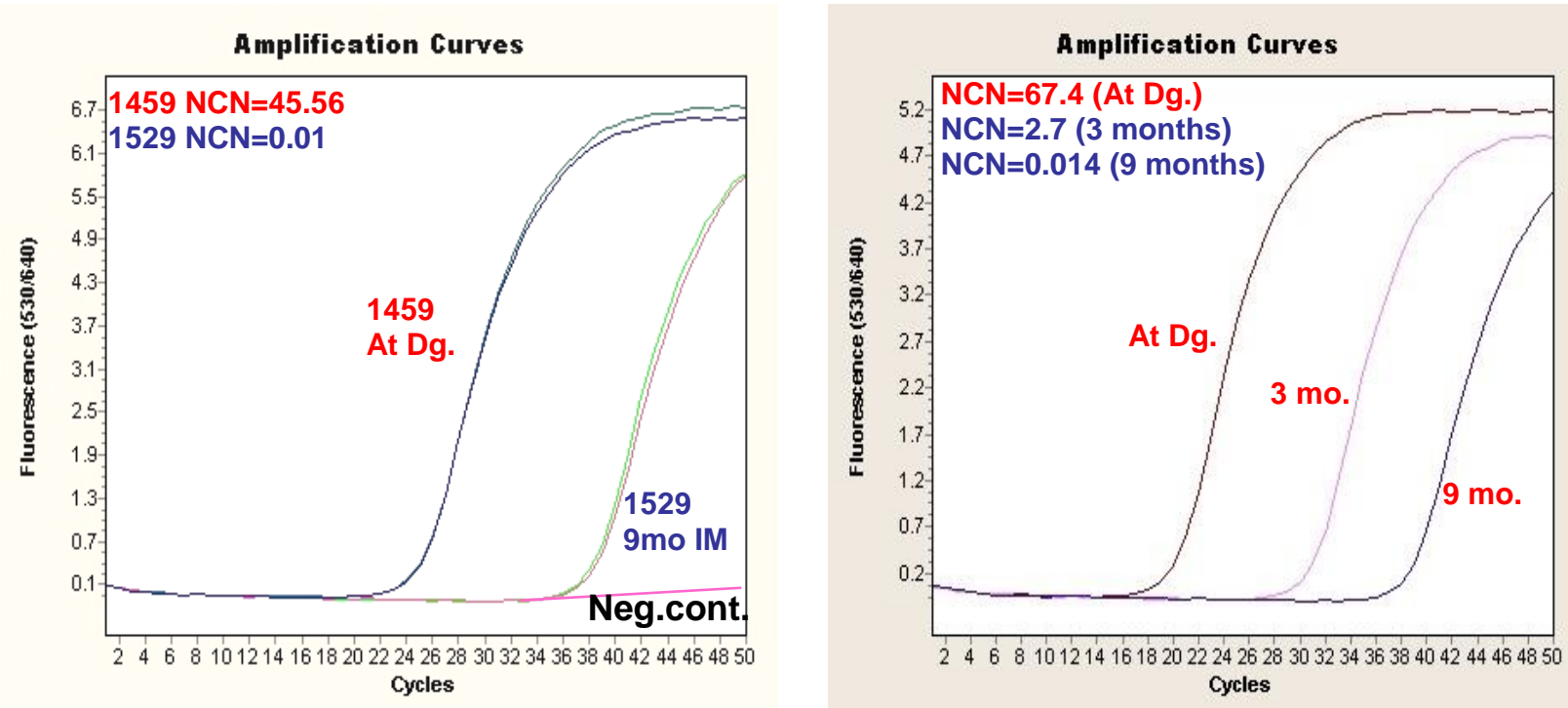

*NCN (Normalized Copy Number) or BCR-ABL1/ABL1 \% in two patients before and after IM treatment and negative control.

Figure 1 - Results of Real Time RT-PCR in patients before and after treatment with Imatinib

Le $\times 10^{9} / \mathrm{L}$

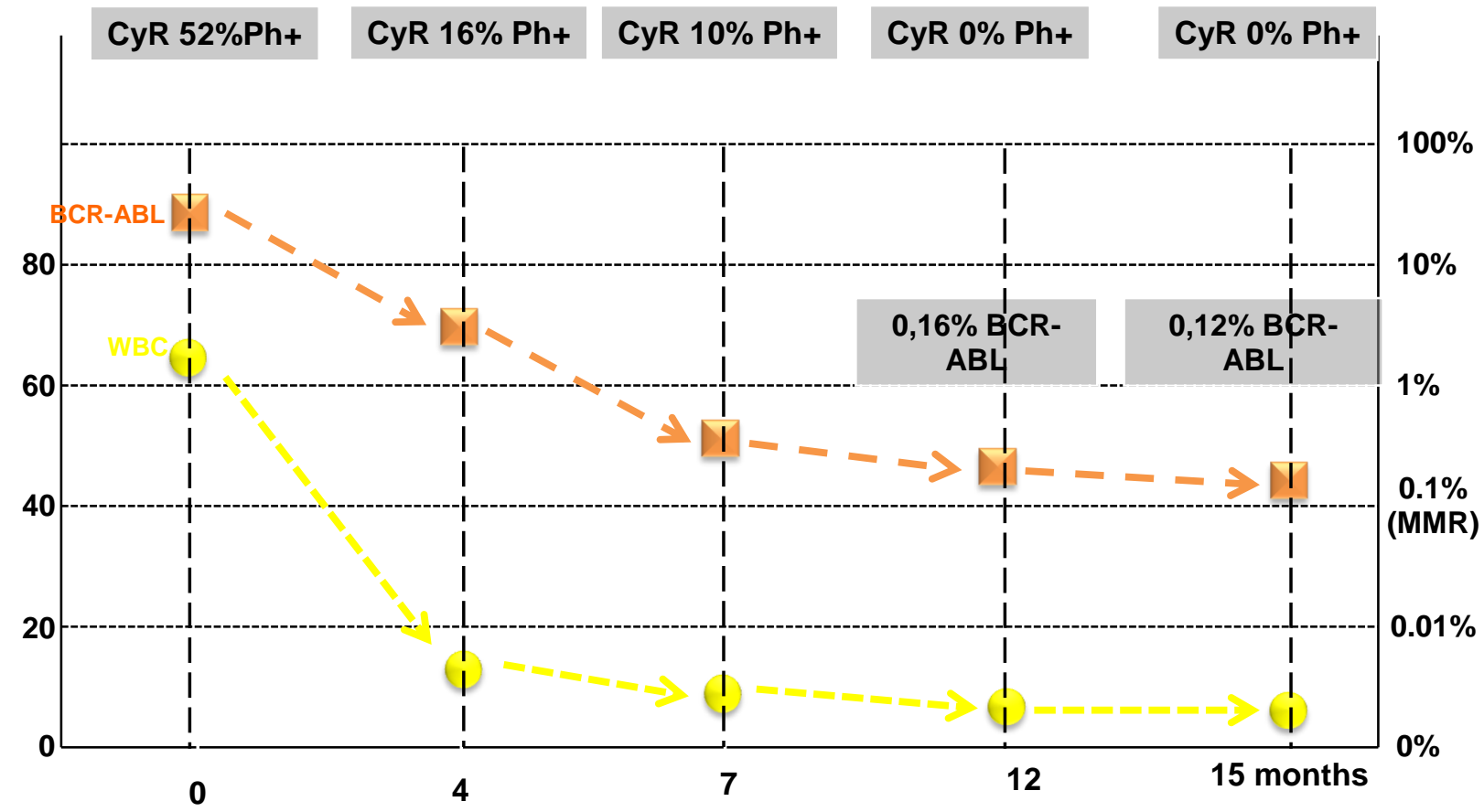

Figure 2 - Hematological, cytogenetic and molecular response during the first 15 months of Imatinib treatment in one of the patients. This patient was in CHR after 3 months of IM treatment, in CCR after 12 months of treatment and did not reach MMR at 15 months of treatment

The cytogenetic data are not presented in this article because such analysis was performed for a very limited number of patients
(9 patients) and 6 of them were in complete cytogenetic response. 
Forty six patients $(87 \%)$ were in complete hematological response and $55 \%$ of pts had MMR (Table 2). From those $55 \%$ of pts that were in MMR, 13/53(24.5\%) pts had MMR at 4.0-4.5 log while 16/53 (30.2\%) pts had MMR at 3.0-4.0 log. MMR was not achieved in 24/53 $(45.3 \%)$. Almost $67 \%$ of the patients (10/15) without prior treatment achieved MMR, while only $50 \%(19 / 38)$ of the patients previously treated with HU and/or Interferon were in MMR. Des- pite the fact that larger proportion of patients achieved MMR when Imatinib was used as a first line therapy $(66 \%$ versus $50 \%)$ this difference was not statistically significant $\left(\chi^{2}=1.2, \mathrm{p}=\right.$ 0.272 ) mostly due to the small number of patients in both groups (15 versus 38 patients). When we compared the characteristics of the patients in MMR at 3.0-4.0 $\log$ with the patients in MMR at 4.0-4.5 log we did not found significant differences in patients characteristic Table 3.

Table 2

Patient characteristics and response to Imatinib therapy

\begin{tabular}{|c|c|}
\hline No of patients & $53(\%)$ \\
\hline Median age, (range), years & $59(18-77)$ \\
\hline Sex (female/male) & $28 / 25$ \\
\hline Median CML duration, years & $6(1-17$ years $)$ \\
\hline Median duration of IM treatment, (range) & $3(1-10$ years $)$ \\
\hline \multirow{2}{*}{$\begin{array}{l}\text { Treatment prior to IM, (range) } \\
\text { No of patients with prior treatment }\end{array}$} & 22 (0-128 months) \\
\hline & \\
\hline \multirow{3}{*}{$\begin{array}{l}\text { First-line treatment with IM } \\
\text { Prior treatment with HU/IFN } \\
\text { Type of BCR-ABL1 transcript }\end{array}$} & $15 / 53(28 \%)$ \\
\hline & $38 / 53(72 \%)$ \\
\hline & Type of BCR-ABL1 transcript \\
\hline $\mathrm{b} 2 / \mathrm{a} 2$ & $21 / 53(39.6 \%)$ \\
\hline $\mathrm{b} 3 / \mathrm{a} 2$ & $32 / 53(60.4 \%)$ \\
\hline $\mathrm{CHR}(\%)$ & $46 / 53(87 \%)$ \\
\hline MMR (\%) & $29 / 53(55 \%)$ \\
\hline MMR in pts without prior treatment $(\%)$ & $10 / 15(67 \%)$ \\
\hline MMR in pts with prior treatment $(\%)$ & $19 / 38(50 \%)$ \\
\hline
\end{tabular}

Table 3

Characteristics of patients in MMR at 3.0-4.0 log and 4.0-4.5 log.

\begin{tabular}{|l|l|l|l|}
\hline MMR & $3.0-4.0 \log$ & $4.0-4.5 \log$ & P value \\
\hline No of patients & 16 & 13 & \\
\hline Median age, (range), years & $56(18-71)$ & $53(18-69)$ & n.s. \\
Sex (female) & 9 & 6 & $\mathrm{P}=0.588$ \\
Median CML duration, (range, years) & $5(1-17)$ & $4(1-13)$ & n.s. \\
Median duration of IM treatment, (range,years) & $3(1-10)$ & $3(1-7)$ & n.s. \\
Treatment prior to IM, (range, months) & $21(0-128)$ & $18(0-68)$ & n.s \\
No of patients with prior treatment & & & \\
$\quad$ First-line treatment with IM & 8 & 7 & $\mathrm{p}=0.662$ \\
Prior treatment with HU/IFN & 8 & 5 & \\
Type of BCR-ABL1 transcript & 6 & 5 & $\mathrm{p}=0.955$ \\
b2/a2 & 10 & 8 & $\mathrm{n} . \mathrm{s}$. \\
b3/a2 & $16(100 \%)$ & $13(100 \%)$ & \\
\hline CHR (\%) & $29 / 53(55 \%)$ & $7(54 \%)$ & $\mathbf{p}=\mathbf{0 . 5 8 8}$ \\
MMR(\%) & $7(44 \%)$ & $6(46 \%)$ & \\
MMR in pts without prior treatment (\%) & $9(56 \%)$ & \\
MMR in pts with prior treatment (\%) & & \\
\hline
\end{tabular}

*n.s. not significant

During the follow up of this group total of 5 patients have died. Three patients died due to disease progression, while 2 patients died from secondary malignancies (metastatic pros- 
tate cancer and aggressive endometrial cancer). One of these two patients was in CCyR and MMR, while the second female patient never achieved CCyR or MMR during the survey, but she died from complication during the treatment of the advanced endometrial cancer. We had to discontinue the IM treatment in 5 patients due to poor treatment response and disease progression. In one patient imatinib was switched to dasatinib, while in 4 patients we switched to hydroxyurea and/or Interferon alpha in order to control the disease progression and the leukocyte count. From those 8 patients (3 that have died from disease progression and 5 that had poor therapy response) 6 were pretreated with hydroxyurea and/or interferon and only two were treated with Imatinib only. The comparison of the treatment response of the patients treated with originator and generic Imatinib could not be performed due to the very small number of patients (only two) who were treated only with originator Imatinib. All other patients were treated with both generic and originator Imatinib for a substantial amount of time. We had to discontinue the IM treatment due to the strong allergic reaction in only one patient. We had to stop the IM treatment temporarily, due to milder adverse reactions in 5 pts. The most common adverse reactions were leucopenia, thrombocytopenia, periorbital edema, nausea and gastrointestinal discomfort, but they were mild and short-lasting.

\section{Discussion}

The Imatinib treatment as a front line therapy in patients with CML in chronic phase is associated with high rates of complete cytogenetic and major molecular response, althoughugh significant numbers of patients do not achieve MMR and continue to be at risk for disease progression $[7,16]$. The Imatinib treatment dramatically improved the overall survival and progression free survival of CML patients in the last two decades [8] and the therapy with TKIs become a successful and routine firstline treatment of CML patients. The overall molecular response rate in our group of patient was $55 \%$, compared to the other studies of imatinib as first-line therapy where the percentage is higher $[7,8,17]$, mostly due to the long period of pretreatment with hydroxyurea and/or interferon alpha and longer disease duration before starting the IM treatment. The majority of the patients $38 / 53(72 \%)$ were in late chronic phase and had already received various lines of previous therapies, thus representing a high-risk population.

Our results have shown that higher percentage of patients $66 \%(10 / 15)$ without prior treatment to IM were in MMR compared to $50 \%(19 / 38)$ of the patients previously treated with $\mathrm{HU}$ and/or Interferon, but this difference was not significant $p=0.272$ Table 2 . The percentage of patients achieving MMR after firstline treatment with Imatinib in other studies were $53 \%$ after 1 year of treatment, up to $80 \%$ after 4 years of treatment in the IRIS study [16]; $50.3 \%$ after 18 months and $79.3 \%$ after 36 months of follow up in the study of Hehlmann et al. [18]; $63 \%$ after 18 months of treatment in the study of Cortes et al. [19] compared to our results where lower percentage of patients $(66 \%)$ were in MMR after median follow up of 3 years. This smaller percentage of patients in MMR after first line treatment with IM in our group of previously untreated patients could be explained with the small number of analyzed patients. We have analyzed only 15 patients until the publishing of these results and we need to analyze more patients in order to have clear perspective.

The outcome data with a median followup of 6 years (1-17 years) are similar to the results from other studies [7, 17] with similar response rate. The molecular response became an important prognostic factor and predicts the outcome of the patients treated with TKIs. The Patients not achieving BCR-ABL reduction below $10 \%$ at 3 months of treatment with TKIs may face a worse outcome compared to those who achieve this milestone. The patients that do not achieve optimal response, according to the latest ELN recommendations (Table 1) are candidates for switching to an alternative BCRABL inhibitor or allogeneic hematopoietic stem cell transplantation. Molecular monitoring becomes important tool in further therapeutical decisions. In our group of patients we observed better outcome and treatment response in the patients who were in MMR. Twenty four patients did not achieve MMR, 3 of them died from 
disease progression and 7 of these patients were not in hematological remission, compared to 29 patients who were both in MMR and CHR. Only one of these patients in MMR died during the follow up from progressive prostate cancer while he was in complete hematological, cytogenetic and molecular remission.

In conclusion, Imatinib can induce good molecular response in significant number of patients at long term. Our results show that a larger proportion of patients $(66 \%)$ achieved MMR when IM is used as first line therapy, compared to smaller percentage $(50 \%)$ of patients with prior treatment with HU or/and Interferon alpha. These molecular results suggest that significant number of patients in our hospital need therapy change and treatment with more potent tyrosine kinase inhibitors, like Nilotinib or Dasatinib, that are not still available. Incorporation of molecular monitorring into regular follow up is necessary for early prediction of therapy resistance and poor treatment response.

\section{REFERENCES}

1. Nowell PC, Hungerford DA. A minute chromosome in human granulocytic leukemia. Science. 1960; 132: 1497.

2. Rowley JD. A new consistent chromosomal abnormality in chronic myelogeneus leukemia identified by quinacrine fluorescence and Giemsa staining. Nature. 1973; 243: 290-293.

3. Heisterkamp N, Stam K, Groffen J, de Klein A, Grosveld G. Structural organization of the bcr gene and its role in the $\mathrm{Ph}$ ' translocation. Nature. 1985; 315: 758-761.

4. Collins SJ, Kubonishi I, Miyoshi I, Groudine M. Altered transcription of the c-abl oncogene in K-562 and other chronic myelogenous leukemia cells. Science. 1984; 225: 72-74.

5. Druker BJ, Tamura S, Buchdunger E, et al. Effects of a selective inhibitor of the Abl tyrosine kinase on the growth of Bcr-Abl positive cells. Nat Med. 1996; 2: 561-566.

6. Goldman JM, Melo JV. Chronic Myeloid leukemia - advances in biology and new approaches to treatment. N Engl J Med. 2003; 349(15): 1451-64.

7. Hughes TP, Kaeda J, Branford S, Rudzi Z, Hochhaus A, Hensly ML, et al. Frequency of major molecular response to imatinib or intereferon alfa plus cytarabine in newly diagnosed chronic myeloid leukemia. N Eng J Med. 2003; 349(15): 1423-32.
8. O'Brien SG, Guilhot F, Goldman JM, Hochhaus A, Hughes TP, Radich JP, et al. International Randomized study of Interferon versus STI571 (IRIS) 7year follow-up: sustained survival, low rate of transformation and increase rate of major molecular response (MMR) in patients (pts) with newly diagnosed chronic myeloid leukemia in chronic phase (CMLCP) treated with imatinib (IM). Blood. 2008; 112: Abstract 186.

9. Baccarani M, Deininger MW, Rosti G, Hochhaus A, Soverini S, Apperly JF, et al. European Leukemia Net recommendations for management of chronic myeloid leukemia: 2013. Blood. 2013; 122(6): 872-884.

10. Apperley JF. Part I: mechanisms of resistance to imatinib in chronic myeloid leukaemia. Lancet Oncol. 2007; 8(11): 1018-1029.

11. Apperley JF. Part II: management of resistance to imatinib in chronic myeloid leukaemia. Lancet Oncol. 2007; 8(12): 1116-1128.

12. Soverini S, Hochhaus A, Nicolini FE, et al. BCR$\mathrm{ABL}$ kinase domain mutation analysis in chronic myeloid leukemia patients treated with tyrosine kinase inhibitors: recommendations from an expert panel on behalf of European Leukemia Net. Blood. 2011; 118(5): 1208-1215.

13. Cortes JE, Talpaz M, Giles F, et al. Prognostic significance of cytogenetic clonal evolution in patients with chronic myelogenous leukemia on imatinib mesylate therapy. Blood. 2003; 101(10): 3794-3800.

14. Deininger MWN, Cortes J, Paquette R, et al. The prognosis for patients with chronic myeloid leukemia who have clonal cytogenetic abnormalities in philadelphia chromosome-negative cells. Cancer. 2007; 110(7): 1509-1519.

15. Lee SE, Choi SY, Bang JH, et al. The long-term clinical implications of clonal chromosomal abnormalities in newly diagnosed chronic phase chronic myeloid leukemia patients treated with imatinib mesylate. Cancer Genet. 2012; 205(11): 563-571.

16. Druker BJ, Guilhot F, O’Brien SG, Gathmann I, et al. Five-year follow-up of patient receiving imatinib for chronic myeloid leukemia. N Engl J Med. 2006; 355(23): 2408-17.

17. De Lavallade H, Apperley JF, Khorashad JS, Milojkovic D, Reid AG, et al. Imatinib for newly diagnosed patients with chronic myeloid leukemia: incidence of sustained response in an intention-to treat analysis. J Clin Oncol. 2008; 26(20): 3358-63.

18. Hehlmann R, Lauseker M, Junk-Munkwitz S, et al. Tolerability-adapted imatinib $800 \mathrm{mg} / \mathrm{d}$ versus 400 $\mathrm{mg} / \mathrm{d}$ versus $400 \mathrm{mg} / \mathrm{d}$ plus interferon-alpha in newly diagnosed chronic myeloid leukemia. J Clin Oncol. 2011; 29(12): 1634-42.

19. Cortes JE, Kantarjian HM, Goldberg SL, et al. Highdose imatinib in newly diagnosed chronic myeloid leukemia: high rates of rapid cytogenetic and molecular response. J Clin Oncol. 2009; 27(28): 4754-9. 
Резиме

\section{МОЛЕКУЛАРЕН ОДГОВОР КАЈ ПАЦИЕНТИ СО ХРОНИЧНА МИЕЛОИДНА ЛЕУКЕМИЈА ЛЕКУВАНИ СО ИМАТИНИБ - НАШИ ИСКУСТВА}

\author{
Марица Павковиќ, Росица Ангелковиќ, \\ Марија Попова-Симјановска, \\ Соња Генадиева-Ставриќ, Лидија Чевреска, \\ Александар Стојановиќ
}

Универзитетска клиника за хематологија, Медицински факултет, Скопје, Р. Македонија

Откритието на тирозин киназните инхибитори (ТКИ) значајно го подобри третманот и преживувањето на болните со хронична миелоидна леукемија (ХМЛ). Иматинибот (ИМ) и другите ТКИ индуцираат поголем процент на комплетни цитогенетски ремисии (КЦР), како и поголем процент на мајорни молекуларни ремисии (ММР). Резистенцијата кон ТКИ, сепак, е значаен проблем во третманот на болните со ХМЛ. Цел на оваа студија беше анализа на молекуларниот одговор кај болните со ХМЛ лекувани со ИМ во нашата клиника.
Анализиравме вкупно 53 болни со ХМЛ, 28 жени и 25 мажи, лекувани со иматиниб како прволиниска или второлиниска терапија. Само 15 пациенти беа лекувани со ИМ како прволиниска терапија, додека 38 болни беа претходно третирани со хидроксиуреа и/или интерферон алфа. Медијана на траење на болеста беше шест години (1-17 години). Медијана на должината на лекувањето со иматиниб беше три години (110 години). Молекуларниот одговор беше анализиран во 1-8 временски точки со помош на квантитативен RT-PCR метод.

Комплетна хематолошка ремисија постигнаа 46 пациенти (87\%), додека 55\% од болните постигнаа ММР. Од тоа, 13/53 (24,5\%) болни имаа ММР на 4,0-4,5 лога и 16/53 (30,2\%) пациенти имаа ММР во ранг од 3,0-4,0 лог. ММР не постигнаа 24/53 (45,3\%).

Нашите резултати покажаа нешто помал процент на болни кои постигнале ММР, поради претходен подолг третман со хидроксиуреа и/или интерферон. Подолгото траење на болеста и пролонгираниот третман пред почнување на терапијата со ИМ се најзначајни ризик-фактори за акумулација на дополнителни молекуларни и цитогенетски абнормалности, поради што се јавува резистенција на ТКИ и полош тераписки одговор.

Клучни зборови: хронична миелоидна леукемија, тирозин киназни инхибитори, молекуларен одговор 